\title{
ASSESSMENT OF NEWSAPERS PATTERN OF REPORTAGE ON PUBLIC ACCOUNTABILITY ISSUE IN NIGERIA
}

\author{
Chibuike Julius Nwosu \\ Department of Mass Communication \\ Nnamdi Azikiwe University, Awka \\ nwosujuliusc@yahoo.com
}

\section{Adaobi Olivia Okeke}

Department of Mass Communication Nnamdi Azikiwe University, Awka Findolivia2k3@gmail.com

\begin{abstract}
The issue of public accountability no doubt remains an important factor in both private and public spheres of Nigerian society. It has not only generated much controversy but has been pointed out as one of the factors in Nigeria's twisted political and economic development. As with other social values, the extent public accountability is realised in a society may depend a lot on how much the media put it in public agenda. Therefore, this study investigates how Nigerian newspapers have covered public accountability issues in the last six months of President Muhammadu Buhari's administration. Situated within the agenda setting theory, the researchers adopted content analysis as their study design sample of 48 editions of The Guardian and Daily Trust (24 editions) were selected. Analysis was quantitative using simple percentages. Findings showed that Nigerian newspapers gave frequent coverage to public accountability-related issues and that they gave prominence to these issues. It was also established that the newspapers did not give depth to most of their reports on public accountability-related issues and that the papers were more reactive than pre-emptive in their coverage of such issues. The study concluded that there is still need for improvement in the press coverage of issues of public accountability, particularly by placing more importance on investigative journalism in approaching such sensitive reportage.
\end{abstract}

Key words: Accountability, Public Accountability, Newspaper coverage, Reportage.

\section{INTRODUCTION}

Benhart and Benhart (1976) n Uchenna, (1993, p.127) define public accountability as "The state of being held responsible for carrying out ones obligation". It is not usually a situation of blame- placing, as generally misconstrued, but rather places on an individual, the liability of being called to account for, or tell detail about ones stewardship. Public accountability reflects not only the need for individuals to be accountable towards public stewardship, but also that of the government and its agencies to serve the public effectively by conducting its affairs in accordance with the law of the state. The above assumption is premised on the fact that in every well run democratic government, the culture of public accountability is supposedly, a natural part of the administrative process. At least in principle, it takes natural turn in the wheel of activities during parliamentary and periodic elections when citizens and their representatives in legislature assess and re-assess political office holders for re-election. Sadly, in Nigeria today, the democratic opportunities for public accountability are nonexistent, at best, they might be said to be rudimentary (Nzeribe, 2007, p.66), it is based on the foregoing that this study sought to evaluate the role of the media as it concerns issue of public accountability. The researchers intend carry out this investigation vis-à-vis media's coverage of public accountability issues in Nigeria. 


\section{STATEMENT OF PROBLEM}

Nigeria has continued to go through periods of challenges that revolve mostly around political, economic, social, and at other times, environmental issues, just like other countries of the world, the supposed "Giant of Africa" has struggled to address these challenges, sometimes; she's become successful, and at other times, partially successful and or even failed. Prominent among the factors that have continued to put a cog in the wheel of Nigeria's growth is the issue of poor execution of public accountability by public officials - this has somewhat led to a situation where public offices are brazenly abused and the abusers, most times, go scot free. A particular case in point is that of the Petroleum Trust Fund saga where were the sum of 81.5 billion was misappropriated between October 2019 to May 2020 without proper accountability - a situation that led to a show of shame as demonstrated by a Nigerian professor of Microbiology - Professor Pondei. More so, the level of corruption and poor public accountability that followed the disbursement of the sum of more than 50 billion naira released to cushion the effect of the Corona Virus pandemic which ravaged the world in 2020 raises issues of great concern.

On the other hand, it might be instructive to note that the media apparently occupy a critical position in the society's quest to understand itself, act meaningfully on the social realities surrounding it. To this extent, what the media reports is what is seen to exists and what they fail to report may never be taken to be real or serious (Agba, 2002, p.123). What the above assertion presupposes is that the media remains one of the most important and effective mirror, through which every society sees, assesses and basically understand itself (Agba, 2002, Nwosu, 2019). It therefore stands to reason that the media remains critical element in every society, since their manner of coverage could determine the strength or weakness of certain factors which decide the growth of the society (Awoonor, 2008; Oso, 2008). Nevertheless, the media is not only expected to bring such sensitive issues like public accountability to the front burner, but turn them to public agenda, as such effort will help a responsible government take actions. It is in the view of this nagging problem that this paper interrogates the nature of newspaper coverage of public accountability issues in Nigeria.

\section{OBJECTIVES OF THE STUDY}

The general objective of the study is to investigate how Nigerian newspapers covered issues of public accountability during the last six months of President Buhari's administration that is from May 29, 2018 to November 29, 2019 - a period that was replete with a plethora of economic, political, religious, economic and security challenges. Primarily, the intent is to discover some of the trends that may have significantly defined media reports on these issues. However, in more specific terms the study focus is on the following objectives:

1. To find out the proportion of selected Nigerian Newspapers that published reports related to public accountability issues during the last six months period of President Buhari administration.

2. To find out the level of prominence these newspapers gave to public accountability stories.

3. To find out whether these newspapers gave depth to these public accountability stories.

4. To determine how proactive or reactive these newspapers were in their reportage of public accountability issues. 
The following research questions are formulated to guide the study:

1. How frequently do Nigerian newspapers published reports related to public accountability issues?

2. To what extent do Nigerian newspapers give prominence to public accountability issues?

3. To what extent do Nigerian newspapers give depth to public accountability-related reports?

4. How proactive or reactive were Nigerian newspapers in their coverage of public accountability-related issues.

\section{THEORETICAL FRAMEWORK}

The concern about media coverage of issues have particularly centered on the agenda setting function of the media (Allan, 2013). It is based on this argument that this study adopts the agenda setting theory of Mass Communication as its theoretical anchorage.

The agenda setting theory demonstrates how the media confers prominence on issues by virtue of the manner it portrays them. The theory particularly argues that "the media may not tell us what to think, but certainly tell us what to think about" (Baran, 2010, p.203).

Discussing from the historical perspective of the theory, Golan and Wanta (2016, p.83) note: "The agenda setting theory was introduced in 1972 by McCombs and Daniel Shaw in their study of the role of the media in 1968 American presidential election, in Chapel Hill North Carolina"

Here, the authors carried out a survey of 100 undecided voters during the election on what they thought were key issues on the election, and measured this against the media content. The ranking of the survey showed that the media somewhat positions the agenda for public opinion by expressing specific topics.

The general notion of the agenda setting theory however is that the press does more than bring issues of importance to a level of political awareness among the public. In other words, the main idea of the theory is that priorities of the press to some degree become the priorities of the public. This is so because most times, what the press emphasizes is in turn emphasized privately and publicly by audience of the press (Uwakwe, 2010, p.186).

Okunna (2010, p.130) lends credence to the above view when she argues that "the press somewhat sets political agenda for the society by deciding what political topics people talk about" The media in other words decide on what they think should be priority considerations of the public concerns; be it financial, political, economic, social or other important issues. The underpinning factor therefore is that the media can easily elevate an issue to prominence and in doing so attract attention to such issue (Kosicki, 1993, Baran and Davies 2009; Cesar, 2010)

Viewed from the crust of this theory therefore, it becomes instructive to note that based on the vital nature of the issue of public accountability as a core consideration in a democratic political period like the present President Buhari administration in Nigeris, it remains increasingly essential to set it as a public agenda. In other words, it might be right to argue that when the media sees public accountability issues as salient and central to the overall 
development of the society and correspondingly gives it attention; setting it as a public agenda, it no doubt will precipitate reasonable action from the government and as it were, catalyze changes in the areas reported. More so, when the issue of public accountability is set as a public agenda, it certainly stimulates a platform to ensure integrity, accountability and liability for public officials.

\section{REVIEW OF LITERATURE}

\section{Understanding the Concept of Accountability?}

In ethics and governance, accountability is looked at as: answerability, blame worthiness, liability and the expectation of account giving (Clarence, 2008, p. 60). As a core aspect of governance, accountability has remained an essential discussion related to the challenges of the public sector, non-profit and private, corporate and individual contexts (Reyes, 2006, p.220). In leadership roles, accountability is the acknowledgement and assumption of responsibility for actions, products, decisions and policies; including administration, governance and implementation within the scope of the role or employment position. It encompasses the obligation to report, explain and be answerable for resulting consequences (Reyes, 2006, p.234). In governance however, accountability today has gone beyond the basic definition of being called to account for ones actions (Mulgan, 2000, p.12), it is thus frequently discussed as an account-giving relationship between individuals - here, Mr. A is accountable to Mr. B when Mr. A is obliged to inform Mr. B about Mr. A's (past or future) actions and decisions, to justify them and suffer punishment in case of eventual misconduct (Schedler, 1999, p.17).

Furthermore, it might be crucial to note that accountability cannot exist without proper accounting practice; hence, an absence of accounting would mean absence of accountability. Therefore, it is correct to note that every healthy society becomes increasingly successful when it has its quests and aspirations fulfilled. The success of such society however revolves around the fact that they understand the importance of holding institutions and their leaders accountable for their actions. (Schedler, 1999, p.17; Nwosu, 2013. p.123).

In governance therefore, the purpose of accountability is to uphold fundamental and underlying principles such as: public interest, public trust, rule of law and good governance (Idumange, 2012, p.2). The word accountability thus defines the expectation of the public pertaining to the responsible exercise of political power, vis-à-vis such matters as financial probity in government, the behavioral integrity of officials and protection of the less privileged. Accountability, especially as it pertains to governance describes how authority is distributed in governmental system and how those who hold such authority are held to account for it". In democracy, accountability describes the relationship between those entrusted with public power and the people who entrust such power on them (Nzeribe, 2011.p.156). Accountability is thus, "clear commitments that in the eyes of others have been kept" (Jackson, 2011, p.1)

\section{The Concept of Public Accountability}

Nwahunnaya (1996, p.78) defines public accountability as "The state of being held responsible for carrying out obligation to the public or society". The author argues; "public accountability as generally misunderstood is not: "blame placing, but placing on the individual the liability of being called to account or tell in detail about ones stewardship" Uchenna (1996) similarly views public accountability as: "the comprehensive account of 
one's tenure of public office or authority to ensure that one carries out his or her functions creditably" In other words, public accountability reflects the need for the government and its agency to serve the public effectively by conducting its affairs in accordance with the law of the land (Chowdhury \& Khan, 2000).

Public accountability is the obligation of persons or entities entrusted with public resources to be answerable for the physical, managerial and programme responsibilities that have been conferred on them, and consequently report to those that have conferred this responsibility on them (Chowdhury and Khan, 2000, p.33). From the foregoing, it becomes clear that public accountability is to a certain extent ethical in nature. As an ethical concept in governance; Dubnick (2002) argues that "it does not only deal with individuals, but institutions and the government" Here, at one end is the person who responsibility is handed over to; this person is expected to be accountable while carrying out the responsibility handed over to him or her and at the other end is the person who expects that accountability is properly rendered - to these two people, is the responsibility of ensuring that there is accountability; one makes sure that he gives accounts for stewardship and the other insists that accountability be rendered public accountability therefore from the foregoing, becomes a two-way thing. It is the above regard that (Dubnick, 2002) argues that that "public accountability is a two-way process and cannot exist without clarity, transparency and proper accounting from both parties"

More so, no government all over the world that pays lip service to public accountability survives - the reason being that such government will suffer from crass mismanagement of funds and deadly blows of corruption. Against the foregoing therefore, it becomes understandable to argue that in every properly run government, the concept of public accountability remains non-negotiable (Dubnick, 2002 p.123).

\section{Nigeria and the Culture of Public Accountability}

It is important to note that the public requires public officers to be accountable by demonstrating effective use of public assets and funds in delivery of services and pursuit of government objectives (Obaze, 2006). Interestingly today, in most advanced countries of the world and some African countries, it is the right of the citizens to demand and know the level that activities of their elected public officers are in tandem with the constitutional provisions of such country.

It was on this premise that such laws like: The Declaration of Rights of Citizens incorporated in the preamble of French Constitution which noted that "the society has right to require of every public agent an account of his administration...All citizens have right to decide either personally or through their representatives, as to the necessity of public contribution and to know what uses it is put" become increasingly relevant (Turc 1971, cited in Akinbuli, 2003, p.1). Nigeria equally is not an exception in this regard, as the issue of public accountability should as well assume pivotal position in its polity. The above statement is supported by the fact that over the years, there has been continuous creation of public agencies to curb and possibly address the destabilizing effect of zero attention to public accountability issues, such agencies like Economic and Financial Crime Commission (EFCC), Independent Corrupt Practices Commission (ICPC) etc. Sadly however, these efforts have always been truncated by corruption and deficiency on the part of the government to address these challenges. Akindele (2000, p.123) attributes the above challenge to nothing but "poor culture of public accountability" which he strongly argues "gained roots in the country from independence" 
While investigating on the extent that government officials in Nigeria have been able to embrace the culture of public accountability, Akindele (2000) argues, "Sadly in the last few decades, the culture of public accountability has eluded the Nigerian society, this cruelty is evidenced in the way Nigerian leaders have controlled the country's socio-political landscape; balkanizing and rendering it poor through consistent looting and stealing, yet, go free, seek re-election and succeed to continue from where they stopped stealing in their looting". Akindele (2000), further laments that "even the machineries set to ensure that there is public accountability have in themselves failed"

Onah and Amujiri (2010, p.20) also concur with Akindele (2000) as they clearly illustrate the diminishing culture of public accountability in Nigeria this way: "Public accountability in Nigeria has remained a form of rhetoric, the more emphases that is placed on it, the more it becomes "no matter" in the practice of office holders in." They further argue that "Instead of the leadership to ensure public accountability in Nigeria, most public officers prefer to display practical wealth, which they acquired through criminal disservice". Again, Onah and Amujiri (2010, p.145) also argue that "It is this lack of public accountability culture that is responsible for the total distrust that the public has developed in our leaders" It is this type of poor culture of public accountability that would warrant the show of shame displayed by Pondei, a Professor of Microbiology who slumped while being questioned by a probing panel in the House of Representatives over the alleged misappropriation of N81.5 billion naira fund allocated for the development of the country. Disappointingly, up till today, none of the public officials involved in this corrupt practice have been called to other or the case probed.

Tracing the history of poor culture of public accountability, Uchenna, (1996 p.124) reveals "the poor public accountability culture in Nigeria is traced to the colonial time, when the 'colonist property' was seen as not our property". The impression held sway and somewhat encouraged among Nigerians, the culture of vandalism and looting against the society over that of accountability, probity and liability" This view, Uchenna (1996), argues "accounts for what later degenerated to total disregard for public property, lack of public trust and concern for public goods as collective national property"

Regrettably, Nigeria has suffered from this phenomenon over the years, both in the military and the civilian administrations. The inability to enshrine a strong culture of public accountability in Nigeria revolves around the fact that the country has not really built strong institutions with leaders who are accountable to the public and mechanism to ensure that misused public funds are dearly paid for - this type of system worked in China, where public officials are very careful with public funds (Onah and Amujiri 2010, p.20). To address the issue, Onah and Amujiri (2010) argue that "There is the uncompromising need to build a mechanism that will comply with the terms of public accountability and transparently reporting on performances". More so, since poor culture of public accountability seems to be part of Nigeria's historical experience, it will take very serious effort and systemic overhaul to address it (Onah and Amujiri 2010).

\section{Public Accountability and the Media}

The role of the mass media in every society is predominantly to inform, educate, entertain and also guide against deviation from the acceptable standards of behaviour (Ndolo, 2009, Udeze 2009, Omenugha, 2012; Nwodu 2009). Without reliable information, it would not be feasible for the citizens and those in place of authority to use their power effectively, nor would they be aware of problems and issues that need active considerations. However, since 
the media is the main source of information and vital link between the government and the citizens they are an indispensable precondition for public accountability. Voltmer (2000) underscores this fact when he avers that:

The daily flow of news through the media generates a "running tally" of the government's policies, political events and the actions of the political officials on the bases of which citizens make their choices. They are also expected to provide a forum where a wide range of voices, opposition parties, civil society actors, independents and ordinary citizens can express alternative views. Moreover, they are seen as fourth estate, thus locating the media alongside other branches of government who provide system of checks and balances to control political officials and prevent the misuse of power.

In section 22 of 1999 constitution, the media has been given the role to ensure that the government at all levels is accountable to the citizenry. Moreover, whenever corruption is checked in the conduct of public business, the media usually plays a critical role. It is against this premise that Jibo and Okosi Simbeni (1999, p.54) carefully traces the task of the media in the successful coverage of the water gate scandal, they write: "In the United States, the role of the media in calling to order, the government of Richard Nixon in 1974 cannot be overemphasized as they provided the platform for that government to be accountable to the people".

However, irrespective of the fact that the media carries out these roles, it might be shocking to note that they have really not carried them out in respect to proactive coverage of public accountability - proactive in the sense that when journalists cover ahead of time issues that deal with public accountability, people who are involved in such areas become careful, knowing that there is a beam light on them which would expose any form of corruption (Jibo and Okosi Simbeni 1999). .

\section{Factors That Militate Against Public Accountability in the Media}

Unfortunately, there are factors that continue to militate against the effective coverage of public accountability in Nigeria and most third world countries. Outlining these factors Ndidi, (2006, p.19) writes:

Some of the factors that have constituted impediments towards the effective coverage of public accountability issues today include: poor tools and skills of investigative journalism, the embedded nature of the media in the social sphere, commoditization and commercialization of news items, the adversary relationship of the media.

Ndidi (2006, p.123) puts it more aptly:

Journalism profession has been noted to be successful in the advanced economies because of the extensive usage of investigative journalism. This explains the reason corrupt officials are brought to book and at times, blacklisted from participating in politics. Disappointingly, in Africa, especially Nigeria and some of the developing countries of the world there seems to be lack of investigative apparatuses and skills for effective journalism. Again, the problem of "embeddedness" of the media within the same structure they are trying to censure constitutes big challenge to her effort to fight against the problem of adherence to public accountability regulations. This is so because the capitalist nature of the mainstream media tends to leave them as a mere tool in the hands of powerful political interest in the society. Again, commercialization of media is also a big challenge in the responsibility the media owes to the society. We see a system where the media are owed by the same individuals who misappropriate public funds here they use the same tool that would have fought them to fight for themselves. Moreover, the media is operated like any other business - here, the primary objective is to make profit and remain in business.

Consequently, the result of such practices will not only frustrate the effort of the media to proactively, objectively and dispassionately report public accountability issues in a society but create a type of platform where media practitioners (print and electronics) hobnob with 
politicians, whose ills they are supposed to expose through purposeful reportage. This type of relationship produces a brand of journalism which Professor Sunny Udeze calls "the Otimkpu journalism" a situation where journalists become sycophants than professionals, who through their reports expose the ills of society.

\section{STUDY TECHNIQUE/METHOD}

Content analysis was chosen for this study as a result of the nature of the data sought to be generated. These data are embodied by the newspaper issues sampled for the study and can be accessed via analysis of the newspaper content.

\section{POPULATION OF THE STUDY}

The study population was all national newspapers published in Nigeria within the first six months of President Muhammadu Buhari's administration; May 29, 2015 to November 29, 2015. This decision was informed by the fact that the administration prioritised anticorruption fight and promotion of public accountability. Thus, the last year of the administration can be considered apt for assessing press coverage of public accountability issues.

\section{SAMPLE AND SAMPLING}

The researchers chose The Guardian and Daily Trust newspapers. This choice was informed by the desire to have representation of papers circulating mainly in the Northern and Southern parts of the country. While Daily Trust circulates mainly in the North, The Guardian circulates mainly in the South. The sample size for the study was 48 newspaper editions; this size was chosen based on Basden and Wright's (1997) recommendation that selecting one edition per week will be appropriate for a newspaper study extending up to a period of six months. Hence for each of the two newspapers used here, 24 editions were selected. These on the whole amounted to 48 editions.

The sample selection was conducted in two stages, the first stage involved the selecting of newspaper titles, wherein the researchers looked out for two major characteristics, first: the market strength of the title and second: the ethnic background of the owner. Hence, the researchers purposively selected The Guardian and Daily Trust. The second stage of the sampling involved choosing the particular editions of the two newspaper titles. Hence, the researchers aim was to ensure that every day of the week (excluding Saturday and Sunday) was duly represented. The weekend editions were excluded being that their content and style are more in the nature of magazine than newspaper. In other words they don't usually represent the typical newspaper tradition in terms of content and style (Bellhouse, 2005). In ensuring that the days of the week were evenly represented, the researcher was guided by Basden and Wrights recommendation (1997) that selection of editions should occur in a regular interval that would ensure that successful days are chosen every other week. Thus, the researchers began picking the first day, Tuesday, May, 29, 2015. Then moving to the second week, they chose Monday edition (June 1), the third week, the Tuesday edition (June, 9), the fourth week, Wednesday, June 17 and so on. This process continued up to the last week of November, 2015, where the Monday edition (May 30) was chosen. On the whole, 24 editions for each of the newspapers and 48 editions for the two newspapers became the sample.

\section{UNITS OF ANALYSIS}

The unit of analysis for the study were news, features and editorials. 
DOI: https://doi.org/10.47851/naujocommed.v2i1.105

\section{INSTRUMENT OF DATA COLLECTION}

A coding sheet was used as the data collection instrument. The researchers were assisted by coders who were first trained and an inter-coder reliability test conducted, using Kappa formula as put forward by Cohen (as cited in Lombard, 2010). The test result stood at 0.96 which amounted to $96 \%$ reliability. Data was quantitatively analysed using simple percentages.

\section{DATA PRESENTATION AND ANALYSIS}

The data extracted from the newspapers were presented in statistical tables after their frequencies and corresponding percentages were obtained and the Statistical Package for the Social Sciences (SPSS) utilized in computation. The research questions were answered by interpreting the statistical relationship among the important independent and dependent variables.

\begin{tabular}{lcc} 
& $\begin{array}{c}\text { Table 1 } \\
\text { News Reports } \\
\text { The Guardian }\end{array}$ & \\
\hline News story & $92.4 \%(\mathrm{n}=85)$ & $88.2 \%(\mathrm{n}=142)$ \\
\hline Feature & $2.2 \%(\mathrm{n}=2)$ & $7.5 \%(\mathrm{n}=12)$ \\
Editorial & $5.4 \%(\mathrm{n}=5)$ & $4.3 \%(\mathrm{n}=7)$ \\
\hline Total & $\mathbf{1 0 0 \%}(\mathbf{n}=\mathbf{9 2})$ & $\mathbf{1 0 0 \%}(\mathbf{n}=\mathbf{1 6 1})$ \\
\hline
\end{tabular}

Table 1 shows that $92.4 \%$ of the reports in The Guardian came as news story, $2.2 \%$ came as feature, $5.4 \%$ came as pictorial; while $5.4 \%$ appeared as editorial. In Daily Trust, $88.2 \%$ of the accountability related reports came as news, $7.5 \%$ came as feature, while $4.3 \%$ appeared as editorial.

Research Question 1: How frequently have Nigerian newspapers published reports related to public accountability?

To answer this question, the researchers relied on Table 2 below.

Table 2

\section{Frequency of Coverage}

\begin{tabular}{lcc} 
& The Guardian & Daily Trust \\
\hline $\begin{array}{l}\text { Editions with news on public } \\
\text { accountability }\end{array}$ & $100 \%(\mathrm{n}=24)$ & $88.9 \%(\mathrm{n}=21)$ \\
\hline $\begin{array}{l}\text { Editions without news on public } \\
\text { accountability }\end{array}$ & $0 \%(\mathrm{n}=0)$ & $11.1 \%(\mathrm{n}=3)$ \\
\hline Total & $\mathbf{1 0 0 \%}(\mathbf{n}=\mathbf{2 4})$ & $\mathbf{1 0 0 \%}(\mathbf{n}=\mathbf{2 4})$ \\
\hline
\end{tabular}

Table 2 shows how stories on the issue of public accountability were distributed across the two newspaper titles studied. Here, the data indicated that The Guardian recorded $100 \%$ of the public accountability-related reports. On the other hand, $88.9 \%$ of the editions of Daily Trust contained such reports while $11.1 \%$ did not.

Based on the foregoing, the answer to the first research question is that Nigerian newspapers, to a significant extent, published stories on public accountability.

Research Question Two: To what extent did Nigerian newspapers give prominence to public accountability issues? 
In order to provide answer to the above research, the researchers relied on the tables 3,4 and 5.

Table 3

The overall News Placement

The Guardian Daily Trust

\begin{tabular}{lcccc}
\hline Front Page & $19.3 \%$ & $(\mathrm{n}=31)$ & $22 \%$ & $(\mathrm{n}=42)$ \\
\hline Back Page & $7.5 \%$ & $(\mathrm{n}=12)$ & $0 \%$ & $(\mathrm{n}=0)$ \\
\hline Centre Page & $0 \%$ & $(\mathrm{n}=0)$ & $1.7 \%$ & $(\mathrm{n}=2)$ \\
Editorial Page & $3.1 \%-(\mathrm{n}=5)$ & $0 \%$ & $(\mathrm{n}=0)$ \\
Others & $70.2 \%-$ & $(\mathrm{n}=113)$ & $78 \%$ & $(\mathrm{n}=149)$ \\
\hline TOTAL & $\mathbf{1 0 0 \%}-$ & $(\mathbf{n}=\mathbf{1 6 1})$ & $\mathbf{1 0 0 \%}$ & $(\mathbf{n}=\mathbf{1 9 1})$ \\
\hline
\end{tabular}

The above table shows the overall of news placement across the four newspaper titles studied. The table shows that $19.3 \%$ of the public accountability-related reports published by The Guardian appeared on the front page, $7.5 \%$ appeared on the back page; none $(0 \%)$ appeared on the centre page, $3.1 \%$ on the editorial page, and $70 \%$ on other pages. For Daily Trust, $22 \%$ of the reports were on the front page, $0 \%$ on the back page, $1.7 \%$ on the centre page, none on the editorial page, while $78 \%$ appeared on other pages.

Table 4

Page Rating of News

Daily Champion The Guardian The Punch Daily Trust

\begin{tabular}{lllllll}
\hline Page Lead Story & $48.4 \% \quad(\mathrm{n}=60)$ & $36.5 \%$ & $(\mathrm{n}=57)$ & $20 \%$ & $(\mathrm{n}=18)$ & $41.9 \%(\mathrm{n}=78)$ \\
\hline Non Page Lead Story & $51.6 \%(\mathrm{n}=64)$ & $63.5 \%(\mathrm{n}=99)$ & $80 \% \quad(\mathrm{n}=72)$ & $58.1(\mathrm{n}=108)$ \\
\hline TOTAL & $100 \%(\mathrm{n}=124)$ & $100 \% \quad(\mathrm{n}=156)$ & $100 \%(\mathrm{n}=90)$ & $100 \%(\mathrm{n}=186)$ \\
\hline
\end{tabular}

Table 4 show the page rating of the public accountability related stories in the newspapers studied. In Daily Champion page lead stories accounted for $48.4 \%$ of the stories published; The Guardian had $36.5 \%$ of the same lead stories. The Punch had $20 \%$ of the lead public accountability stories while Daily Trust newspapers published $41.9 \%$ of its reports as the lead stories. Conversely, the Daily champion newspapers published $51.6 \%$ of its public accountability stories as non lead. In The Guardian non-lead stories accounted for $63.5 \%$ of the stories; The Punch had $80 \%$ of the stories as non-lead, while Daily Trust newspaper had $58.1 \%$ of reports as non page lead stories.

Based on the foregoing, the answer to the second research question is that the Nigerian press actually gave prominence to issues of public accountability.

Research Question Three: To what extent did Nigerian newspapers give depth to public accountability-related reports?

To answer this research question, we rely on table 5 below.

Table 5

Depth of Report (Excluding editorials)

The Guardian

In-depth Report

$21.8 \% \quad(\mathrm{n}=34)$

Daily Trust 
NNAMDI AZIKIWE UNIVERSITY

Journal OF COMMUNICATION AND MEDL STUDIES

Volume 2 Number 1 Jan-Mar Issue

ISSN:2756-486X (Online)

DOI: https://doi.org/10.47851/naujocommed.v2i1.105

\begin{tabular}{lllll}
\hline Straightforward Report & $78.2 \%$ & $(\mathrm{n}=122)$ & $71 \%$ & $(\mathrm{n}=108)$ \\
\hline TOTAL & $\mathbf{1 0 0 \%}$ & $(\mathbf{n}=\mathbf{1 5 6})$ & $\mathbf{1 0 0 \%} \quad(\mathbf{n}=\mathbf{1 8 6})$ \\
\hline
\end{tabular}

Table 5 shows that $21.8 \%$ of reports published in The Guardian were in-depth while $78.2 \%$ were straightforward reports. For Daily Trust, $29 \%$ were in-depth while $71 \%$ were straightforward reports. Furthermore, when worked out cumulatively, the data indicate that $73.70 \%$ of the public accountability issues were straightforward reports, while only $26.30 \%$ were in depth reports. From the foregoing, it is clear that the Nigerian newspapers paid enough attention to through issues of public accountability, especially through straightforward reports. On the other hand, the data also showed that Nigerian newspapers failed to give in-depth reports on issues of public accountability. Consequently, it would be affirmed that Nigerian newspapers did not give depth to stories of public accountability.

Research Question Four: How proactive or reactive were Nigerian newspapers in their coverage of public accountability-related issues?

In order to provide answer to the above question, the researchers relied on Table 6 below.

Table 6

Timing of Report

The Guardian Daily Trust

\begin{tabular}{lcc}
\hline Pre-emptive & $10.6 \%(\mathrm{n}=17)$ & $9.4 \%(\mathrm{n}=18)$ \\
\hline Reactive & $89.4 \%(\mathrm{n}=144)$ & $90.6 \%(\mathrm{n}=173)$ \\
\hline TOTAL & $\mathbf{1 0 0 \%}(\mathbf{n}=\mathbf{1 6 1})$ & $\mathbf{1 0 0 \%}(\mathbf{n}=\mathbf{1 9 1})$ \\
\hline
\end{tabular}

Table 6 shows the timing of the reports i.e. whether the newspapers were pre-emptive or reactive towards public accountability-related issues. The data show that $10.6 \%$ of reports in The Guardian were pre-emptive report while $89.4 \%$ were reactive. Also, $9.4 \%$ of reports in Daily Trust were pre-emptive report while $90.6 \%$ were reactive. It is instructive to note at this point that based on the data gathered so far, that Nigerian newspapers were more reactive in their manner of reportage towards public accountability issues than they were proactive. Based on the foregoing, it is inferred in answer to the fourth research question that the Nigerian newspapers were not proactive, but reactive, in their coverage of issues of public accountability.

\section{CONCLUSION}

The findings of this study in general suggest some possible suppositions. That the Nigerian populace may have gained from the way Nigerian newspapers gave enormous proportion of their coverage's to issues of public accountability and the way they frequently covered the issues. Perhaps, it was this sort of vibrant reportage that has placed the issue of public accountability on the top list of public agenda, as identified by the findings of this research.

However, the tendency of the press, as observed in the third finding, goes a step further to show that the Nigerian newspapers have not given much interest in the level of depth accorded to public accountability issues. This discovery thus might throws light to the reason the issue of public accountability has not been appropriately dealt with, even in the face of regular reportage it has received from the press" (Iwuchukwu, 2010, p.34) 
Similarly, the last finding also identifies the failure of Nigerian newspapers to treat the reportage of public accountability issues proactively. Reactive press coverage may not be the most appropriate approach to treat issues of national interest of this nature.

\section{RECOMMENDATIONS}

Based on the results of this research and other observations made in its course, the researcher recommends as follows:

i. That Nigerian journalists should be trained continuously on the art of investigative journalism, especially, as it concerns such areas like corruption and issues of public accountability. This will help in a better coverage of public accountability issues and at long run produce a society with the consciousness for public accountability.

ii. Again, journalists should be educated properly on the ethics of the journalism, as this forms the central conduct to the proper practice of journalism profession; curbing such situation where the journalists continue to hobnob with politicians, proprietors of newspaper and public officials for financial gains. This is so because such will always encourage a position of lopsidedness, consequently producing reports are not objective (Okunna 2006) - public accountability issues is not an exception.

iii. Furthermore, Nigerian journalists should not only be encouraged but motivated with reasonable pay packets as this will encourage them to work objectively, rather than act within the whims and caprices of politicians, public office holders and people who reward them in return. Motivation addresses the selfish passion of the human person, who likes to work for economic and social rewards, closely associated with work efficiency" (Owuamalam, 2007, p.312).

iv. Furthermore, while journalists report on issues that bother on public accountability, the government should take bold steps to deal decisively with officials established through $t$ investigative reports to have stolen, diverted, misappropriated or misused public funds and positions, as this is the core of democratic leadership. Such punishment of course, will serve as a deterrent and warning to people who occupy public offices.

\section{REFERENCES}

Abubarkar, H. (2016). Transparency and accountability in local government administration in Nigeria. National workshop on local government structure and potential for socioeconomic development in Nigeria. Ibadan 28 - 30 July.

Agba, P.C. (2003). International communication: principles, concepts and issues. In C.S Okunna (ed) Teaching Mass Communication. (p.247-271). Enugu: New Generation Books

Akindele, I. (2001). Developing professional public administrator for new democratic culture. Journal of Institute of Public Administration 24 (20) 23-26. 
Akumbuli, (2003). Public accountability in local government in administration in Nigeria: The way forward. Journal of Public Administration 1(2), p.35-48

Allan, D \& Bacon, D. (2009). Understanding communication theory: The communicative forces of human action. American Journal of Communication, 10(2), 281 - 313.

Awoonor, G. (2008). The effective use of print media in fight against corruption. Retrieved from http://www.peepsieraloen.com/news/dfcfa

Baran, S.J. (2010). Introduction to mass communication, media, literacy and culture ( $2^{\text {nd }}$ ed.). New York: McGraw Hill.

Baran, S., \& Davis, D.K. (2009). Mass Communication Theory (5 ${ }^{\text {th }}$ Edition). Australia: Woodworth Cengage Learning

Bellhouse, D.R. (2005). Systematic sampling method. Retrieved from http://onlinelibrary.wiley.com/doi/10.1002//0470011815.b2a16077/abstract

Bovens, M. (2005). Public accountability. In C. Ewan, L.E. Lynn \& C Politt (Eds). Public Accountability and Public Officials Oxford: Oxford Press.

Caesar, A. (2010). Strenth and weaknesses of media agenda setting theory. Retrieved from http://anitacaesar.blpgspot.com.2010/05/strenght-and-weakness-of-media-ageda

Chowdery, N. (2006). Public accountability, corruption, control and service delivery: governance, challenges and future options. Retrieved from http://www.uu.content/nwosgovernance.deftext

Claren, R. I. (2005).Public accountability: dilemmas and experiences. New York: Cambridge University Press.

Dubnick, M. (2002). The concept of public accountability. Retrieved from http://www.researchgroup/2.democracyandaccountability.

Dunu, (2004). Good governance, public accountability and the media. Journal of Social Sciences, 2(1), $112-118$.

Duru, H. C. (2014). The metaphor of dwarfish giant: Nigeria in the center of African political discourse. Unpublished paper. Department of Mass Communication Nnamdi Azikiwe University Awka.

Harlow, C. (2002). Accountability in European Union. Oxford: Oxford Press.

Idumamge, I. (2002). Democratic accountability and public trust in Nigeria. Received from http://wwwpointblanknews.com

Ijhewere, O. B. (2013). An examination of anti-corruption crusades in Nigeria: Issues and challenges. The Quarterly Journal of Administration, 33 (1), 108 - 107. 
Izhezhe, I. (2015). Non remittance of 11.63 billion USD paid to NNPC on crude oil swaps due to subsidy and domestic crude oil allocation. Retrieved from

Jackson, I. O. (2011). What is accountability really? Retrieved from https://www.walkthetalk.com/media/sneak_a_peek/lookinside/winning_with_account ability_01.pdf

Kosicki, G. (1999). Problems and opportunities of agenda setting research. Journal of Communication, 43(2), 100-127.

Lawal, O. (2009). Newspaper coverage on corruption. Journal of Communication, 43(2), 113-123.

Mulgan, R. (2000). Accountability: an ever expanding concept. Journal of Public Administration 6(78), 87 - 97.

Ndolo, I.S. (2009). Mass media systems and society. Enugu: Rhyce Kerex Publishers.

Nwahunnaya, C. (1996). Citizen's awareness and orientation: the Nigerian experience. In C. Nwahunnaya (Ed). Higher perspectives of citizenship education(pp.105 - 115). Owerri: Springfield Publishers.

Nwokocha O. A (2015). The challenges of good governance and public accountability in Nigeria. Owerri: Concept Publishers.

Nwosu, T. (2007). Mass media and Nigerian society. Umuahia: The Readers Choice Company.

Nzeribe, (2006). The culture of public accountability in Nigeria: Ibadan: Cardinal press Ltd.

Obaze, O. (2006). Advocacy for good governance. Retrieved from http://thenewschronicle.com/here-to-serve-advocacy-for-good-governance

Okunna, C.S.(1999). Introduction to Mass Communication. Enugu: New Generation Books

Onah, R.C.\&Amujiri, B.A. (2010). Local government in Nigerian structure, role and expectation. National workshop on local government structure and potentials for socio economic development of Nigeria. Ibadan 28 - 30th July.

Elemanya, A. \& McWilliams R. (2016). Analyses of President Buhari's anti-corruption policy: A reality or an illusion. Journal of Advanced Academic Research, 2(11), 77 89.

Oso, L. (2008). The role of the media in anti-corruption reporting. Retrieved from http://www.allafrica.co/stories/200809300369htm.

Oyewole, M.A. (2008). Nigerian print media fight against corruption. Retrieved from http://www.focusnigeria.com/nigria-print-media.htm 
DOI: https://doi.org/10.47851/naujocommed.v2i1.105

Politt, C \& Bourkert, H. (2005). Reflexive watchdogs? How supreme audit institutions account for themselves

Reyes, W. (2008). Leadership and accountability in a globalized world. London: Palgrave Macmillan.

Schedler, A. (1999). Conceptualizing accountability. In A. Schedler, L. Diamond \& M. Platnner (Eds.), The self restraining State: Power and accountability in new democracies. London: Lynne Reiner Publishers.

Uchenna, M.B. (1999). The problem of accountability in contemporary Nigeria. In C. Nwanhunnaya (Ed.), Higher perspectives of citizenship education (pp.105-115). Owerri: Springfield Publishers.

Uwakwe, O. (2010). Introduction to Mass communication in the Digital Age: Print, TV, Film, Internet Industry Effects. Onitsha: Base 5 Publishers. 